\title{
Determination of the reference interval of the C-reactive protein/albumin ratio and its efficiency, CRP and albumin as prognostic markers in $\operatorname{dog} s^{1}$
}

\author{
Andrei K. Fabretti² (D), Raquel C.S. Siqueira ${ }^{2}$ (D) Higo F. Amaral $^{3}$ (D), \\ Daniella A.G. Kemper ${ }^{4}$ (D), Rafael O. Chaves $^{5}$ (D) and Patrícia M. Pereira ${ }^{2}$ (D)
}

\begin{abstract}
Fabretti A.K., Siqueira R.C.S., Amaral H.F., Kemper D.A.G., Chaves R.O. \& Pereira P.M. 2020. Determination of the reference interval of the $\mathrm{C}$-reactive protein/albumin ratio and its efficiency, CRP and albumin as prognostic markers in dogs. Pesquisa Veterinária Brasileira 40(3)202-209. Universidade Estadual de Londrina, Rod. Celso Garcia Cid PR-445 Km 380, Londrina, PR 86057-970, Brazil. E-mail: akfabretti@gmail.com

The objective of this research was to creates a reference interval for C-reactive protein (CRP)/albumin ratio (CAR) in the canine species and to analyze the potential of CRP, albumin and the relationship between both, to serve as indicators of disease severity, length of hospital stay (LoS) and mortality in this species. For this, an outcome study was conducted in a Veterinary Teaching Hospital in southern Brazil. One hundred ninety dogs were included randomly, without distinction of gender, age, or breed, from June 2013 to November 2016. Plasma was collected from them and analyzed for assessment of CRP and albumin. The reference range stipulated for CAR in dogs was $0.36-0.60$, as determined by the confidence interval of mean resamplings (in percentiles). The frequencies mean, and standard deviations of the variables, correlation analysis, and comparative analysis (KruskalWallis in $\alpha=5 \%$ ) were calculated. Elevation (above reference) of CAR was determined to be proportional to the severity of the underlying disease, and CRP means were reasonable. Besides, hypoalbuminemia was indicative of systemic disease, but not of severity. Thus, CAR was a better marker of disease severity than were CRP and albumin, analyzed separately. Concerning LoS, there was a positive correlation with CAR $(p<0.01)$ in patients, and the same was not observed with CRP and albumin. Concerning mortality, hypoalbuminemia was the only marker valid in animals with a critical illness $(\mathrm{p}=0.04)$. In conclusion, CAR is a better marker of disease severity and LoS in dogs than are CRP and albumin analyzed separately.
\end{abstract}

INDEX TERMS: C-reactive protein, albumin, prognosis, mortality, length of stay, disease severity, dogs.

RESUMO.- [Determinação do intervalo de referência e da eficiência da relação proteína C-reativa/albumina, PCR e albumina como marcadores prognósticos em cães.] O objetivo desta pesquisa foi determinar um intervalo de referência para a relação proteína $\mathrm{C}$ reativa (PCR)/albumina (R:PCR/ALB) na espécie canina e analisar o potencial de PCR, albumina e a relação entre ambas como indicadores de gravidade de doença, tempo de internação (TI) e mortalidade nesta espécie. Para isso, um estudo foi realizado em um Hospital Veterinário Escola no sul do Brasil. Cento e noventa

\footnotetext{
${ }^{1}$ Received on September 9, 2019.

Accepted for publication on October 10, 2019

${ }^{2}$ Universidade Estadual de Londrina (UEL), Centro de Ciências Agrárias, Departamento de Clínicas Veterinárias, Rod. Celso Garcia Cid PR-445 Km 380, Cx. Postal 10.011, Londrina, PR 86057-970, Brazil. *Corresponding author: akfabretti@gmail.com
}

cães foram incluídos aleatoriamente, sem distinção de sexo, idade ou raça, de junho de 2013 a novembro de 2016. 0 plasma foi coletado e analisado para avaliação da PCR e albumina. $O$ intervalo de referência estipulado para o R:PCR/ALB em cães foi de 0,36-0,60, conforme determinado pelo intervalo de confiança da média das reamostragens (em percentis). Foram calculadas as frequências, médias e desvios-padrões das variáveis, análises de correlação e análises comparativas (Kruskal-Wallis em $\alpha=5 \%$ ). Notou-se elevação (acima da referência) da R:PCR/ALB proporcional à gravidade da doença

\footnotetext{
${ }^{3}$ Centro Universitário Filadélfia, Departamento de Estatística, Av. Juscelino Kubitscheck 1626, Jd. Higienópolis, Londrina, PR 86010-000, Brazil.

${ }^{4}$ Universidade Norte do Paraná, Curso de Medicina Veterinária, Unidade Arapongas, PR-218 Km 1, Jd. Aeroporto, Arapongas, PR 86702-670, Brazil.

${ }^{5}$ Universidade Caxias do Sul, Curso de Medicina Veterinária, Rua Francisco Getúlio Vargas 1130, Caxias do Sul, RS 95070-560, Brazil.
} 
de base, sendo normais as médias da PCR. Adicionalmente, a hipoalbuminemia foi indicadora de doença sistêmica, mas, não de gravidade. Dessa forma, a R:PCR/ALB foi melhor indicadora de gravidade de doença do que a PCR e albumina, analisadas separadamente. Em relação ao TI, houve correlação positiva com a R:PCR/ALB $(\mathrm{p}<0,01)$ em doentes, não sendo observado o mesmo com a PCR e albumina. Em relação à mortalidade, a hipoalbuminemia foi a única marcadora válida em animais com doenças críticas $(\mathrm{p}=0,04)$. Conclui-se, portanto, que a R:PCR/ALB é melhor marcadora de gravidade de doença e TI em cães do que a PCR e albumina analisadas separadamente.

TERMOS DE INDEXAÇÃO: Proteína C-reativa, albumina, prognóstico, mortalidade, tempo de internamento, gravidade de doença, cães.

\section{INTRODUCTION}

The strong bond of affection between humans and companion animals, coupled with easy access to information (especially online) has generated a high level of questioning of animal owners to veterinarians, with the clinical course of their sick animals (Rabelo et al. 2009, Fabretti et al. 2014). A similar scenario occurs in human medicine (Niewinski et al. 2014, Silva et al. 2014).

In this way, correctly determining a patient's prognosis is an increasingly valued medical action. Prognosis is defined as an early forecast of the patient's progression and chances of recovery based on clinical and diagnostic information from the patient. (Niewinski et al. 2014, Silva et al. 2014). This prediction is useful in several ways in human and veterinary medicine: it supports the type of treatment indicated (at home or in hospital, including intensive care); goal decisions regarding monitoring protocols; estimation of length of hospital stay (LoS); and when applicable, medical costs and chances of survival, as well as providing helpful information for making euthanasia decisions in animal patients (Cockcroft 2007, Rabelo et al. 2009, Davis et al. 2012, Fabretti et al. 2014).

As a tool that directs the patient's clinical conduct and serves as an argument for the veterinarian to receive authorization for expensive procedures, an erroneous estimate can have disastrous consequences, as a wrong choice of medical protocols can result in worse clinical outcomes (possibly death) in addition to the possibility of unnecessary expenses. As a result, conflicts may occur between veterinarians and their clientele (Cockcroft 2007, Rabelo et al. 2009, Fabretti et al. 2014).

For the prognosis to be as precise as possible, it is necessary to use effective markers to predict the severity of the underlying disease, clinical recovery time and chance of death in each case. Among the markers most commonly used in medicine, both human and veterinary, are serum levels of C-reactive protein (CRP) and albumin (Yeun et al. 2000, Cerón et al. 2008, Eckersall \& Schmidt 2014, Fabretti et al. 2014, Wong et al. 2016).

C-reactive protein is the main positive acute phase protein in dogs and an excellent modulator and marker of initial inflammation, being measured as the magnitude of its elevation proportional to the inflammatory level. (Dabrowski et al. 2013, Kjelgaard-Hansen et al. 2013, Christensen et al. 2014, Eckersall \& Schmidt 2014). In dogs and humans, their serum concentration increases four to six hours after injury, and their peak is reached in 24-48 hours. (Davis et al. 2012, Rubio \& Schmidt 2014, Reimann et al. 2016). At this time, in dogs, C-reactive protein can reach serum concentrations above 100 to 1,000 times the reference range, and normalization occurs approximately one to two days after the end of the inflammatory stimulus (Jitpean et al. 2014, Tizard 2014, Venco et al. 2014). Healthy dogs have less than $5 \mathrm{mg} / \mathrm{L}$ of this protein in plasma (Kuribayashi et al. 2003, Jitpean et al. 2014, Rubio \& Schmidt 2014, Reimann et al. 2016).

As a prognostic marker in companion animals, C-reactive protein is especially useful because its increase precedes any leukocyte alteration, enabling the recognition of subclinical disorders (Anziliero et al. 2013, Karlsson et al. 2013, Viitanen et al. 2014). High serum concentrations have been associated with a higher death rate in dogs, with normalizing being associated with clinical recovery (Michelsen et al. 2012, Anziliero et al. 2013, McClure et al. 2013).

In addition, albumin is the most abundant plasma protein, with its main function being to transport nutrients, hormones, metabolites and pigments in blood and tissues (Cerón et al. 2008, Eckersall 2008, Thrall et al. 2015). It is a negative acute phase protein; therefore, its serum level decays in inflammatory processes (Cerón et al. 2008, Eckersall 2008). Albumin is considered, in human and veterinary medicine, a sensitive marker of morbidity, mortality and hospitalization time; in this way, the more serious the disease becomes, the lower the albumin concentration will be, and the worse the prognosis will be (Corkins et al. 2010, Fabretti et al. 2014, Ong et al. 2014, Qin et al. 2016).

One way to increase the accuracy of prognostic stipulation is to use both variables together in the CRP/albumin ratio (CAR). This relationship has been widely used in human medicine recently, with a large number of studies being published since 2013. It is considered an early, independent and reliable marker of prognosis (largely related to mortality), especially in cases of neoplasias or sepsis (Ranzani et al. 2013, Xu et al. 2015, Tao et al. 2016, Guo et al. 2017, Li et al. 2017).

There are authors, in human medicine who report that CAR is a better prognostic marker than several other indicators of inflammation, such as lymphocyte/neutrophil ratio, lymphocyte/platelet ratio, or the use of CRP and albumin separately (Ranzani et al. 2013, Liu et al. 2015, Wu et al. 2016). One advantage is that use is simple and has a high accuracy with a reduced cost compared with other prognostic indicators (Kinoshita et al. 2015, Park et al. 2016).

Although this marker is used in human medicine, there are no known studies, to the best of the authors' knowledge, of this relationship in veterinary medicine of companion animals. Thus, the present work creates a reference interval for CAR in dogs and analyzes the potential of CRP, albumin and the relationship between both as prognostic markers in dogs, studying their correlations with disease severity, LoS and mortality in this species. This study is, therefore, intended to innovate in the prognostic evaluation of dogs.

\section{MATERIALS AND METHODS}

One hundred ninety dogs admitted in a veterinary teaching school hospital, from June 2013 to November 2016, were randomly included in this study, regardless of gender, age or race and with client approval by the informed consent document. The project was approved in the institutional ethical committee, under registration 1679/2013. Exclusion criteria were: animals whose guardians did not agree to the study; animals with clinical dehydration above $8 \%$; blood transfusion 
within 21 days prior to project evaluation; aggressiveness, dyspnea or less than $2 \mathrm{~kg}$ of body weight; nephropathies and proteinuria or liver disease with cirrhosis.

The following patient data were recorded: race, age, gender, hospitalization period (in days), reason for hospitalization and the outcome (discharge or death). The weight was measured in the electronic balance. The severity of the underlying disease was classified according to Disease Score (DS) as described by Muir (2007) and was a parameter for the distribution of dogs in three groups. The first group was the Control Group (CG), which was composed of 40 healthy and asymptomatic dogs. The second group was composed of 80 dogs classified in DS 2 or 3 and was called the moderate diseases group (MDG). These were patients with nondisabling systemic diseases who were able to move, at least at short distances. The third group was called the severe diseases group (SDG), consisting of 70 animals classified in DS 4 and 5, that is, with disabling and critical systemic diseases. These dogs remained in decubitus position.

Blood was collected from the jugular vein and stored in serum tubes ( $2 \mathrm{~mL})$. Samples were centrifuged within 15 minutes at $1500 \mathrm{x}$ $\mathrm{g}$ for 10 minutes, and serum was immediately separated and stored at $-80^{\circ} \mathrm{C}$ until analysis. All analyses were performed simultaneously on each sample.

C-reactive protein and serum albumin analyses were performed in veterinary laboratories. The albumin was measured by the bromocresol green method, analyzed by the semiautomatic apparatus BIO-2000 (Bioplus Products for Laboratories Ltda, Baurueri/SP, Brazil), using colorimetric tests with kits of Analisa brand (Gold Analisa Diagnostica Ltda, Belo Horizonte/MG, Brazil). Additionally, the CRP was analyzed by the ultrasensitive turbidimetric immunoassay technique in the Siemens Dimensions (automated clinical chemistry analyzer), model RXL, with test kits from the same company. The measurements were made according to the manufacturer's instructions and the kits used were validated for use on dogs (Christensen et al. 2014, Viitanen et al. 2014). The laboratory teams did not have access to other data of the studied patients and were blinded to the prognosis of these patients.

For the determination of the reference range of clinical laboratory variables in veterinary medicine, a sample between 40 and 120 is indicated (Friedrichs et al. 2012) This research had 40 samples (CG) for determination of the reference range of CAR; therefore, the data are significant. For that, the confidence interval ( $\alpha=95 \%)$ of the mean of the resamplings, based on percentiles, was calculated using the software BioEstat v. 5.0 (BioEstat - Institute of Sustainable Development Mamirauá/AM, Brazil).

In all groups, the correlation between CRP, albumin and CAR was tested with the prognostic measures of LoS and mortality. Comparative analysis of these variables between groups was allowed to investigate whether they were correlated to the severity of underlying disease.

The means and standard deviations of the variables for CG, MDG and SDG were also investigated. The Pearson correlation between the variables within each group was then analyzed. Finally, the Kruskal-Wallis nonparametric test at $\alpha=5 \%$ (significant) and $\alpha=$ $1 \%$ (highly significant) was used to compare the groups (which did not have the same number of animals). Statistical software Action Stat Pro (Estatcamp - Statistical Consulting and Quality - São Carlos/ SP, Brazil) was used for these analyses.

\section{RESULTS}

One hundred ninety dogs were evaluated in this study. The characteristics of each group are described in Table 1.

In relation to GC, $25 / 40(62.5 \%)$ were admitted for checkup, $14 / 40(35.0 \%)$ for elective castration and 1/40 (2.5\%) for blood donation. The animal assessment and blood collection were performed before the surgeries. Regarding the reasons for attendance in MDG, 27/80 (33.75\%) were due to gastroenteritis, $6 / 80(7.5 \%)$ for pyometra, $3 / 80(3.75 \%)$ due to pancreatitis and the remainder, 44/80 (55.00\%), due to the presence of several other nondisabling systemic diseases. In SDG, these animals were taken to hospital care due to neoplasms 12/70 (17.14\%); heart diseases 9/70 (12.85\%), ehrlichiosis 8/70 (11.43\%) and 41/70 (58.58\%) due to other critical systemic diseases.

The description of CG relative to the values of CRP, albumin and CAR is shown in Table 2. The calculated reference range

Table 1. Description of the groups studied, in relation to sex, race, age and weight of the dogs

\begin{tabular}{|c|c|c|c|c|}
\hline Group & Sex & Races & Age & Weight \\
\hline $\mathrm{CG}^{\mathrm{a}}(\mathrm{n}=40)$ & $\begin{array}{l}\text { Males: } 22 / 40(55.00 \%) \\
\text { Females: } 18 / 40(45.00 \%)\end{array}$ & $\begin{array}{c}\text { Non-breed: } 13 / 40(32.50 \%) \\
\text { Different races: } 27 / 40(67.50 \%)\end{array}$ & $\begin{array}{l}5 \text { months }-10 \text { years } \\
\left(44 \pm 32^{\mathrm{d}}\right)\end{array}$ & $\begin{array}{c}2.3 \text { to } 60 \mathrm{~kg} \\
\left(15.84 \pm 12.49^{\mathrm{d}}\right)\end{array}$ \\
\hline $\mathrm{MDG}^{\mathrm{b}}(\mathrm{n}=80)$ & $\begin{array}{l}\text { Males: } 35 / 80(43.75 \%) \\
\text { Females: } 45 / 80(56.25 \%)\end{array}$ & $\begin{array}{c}\text { Non-breed: } 36 / 80(45.00 \%) \\
\text { Different races: } 44 / 80(55.00 \%)\end{array}$ & $\begin{array}{l}2 \text { months - } 16 \text { years } \\
\left(57.46 \pm 55.50^{\mathrm{d}}\right)\end{array}$ & $\begin{array}{c}2.6 \text { to } 54.6 \mathrm{~kg} \\
\left(13.37 \pm 11.59^{\mathrm{d}}\right)\end{array}$ \\
\hline $\mathrm{SDG}^{\mathrm{c}}(\mathrm{n}=80)$ & $\begin{array}{l}\text { Males: } 42 / 70(60,00 \%) \\
\text { Females: } 28 / 70(40,00 \%)\end{array}$ & $\begin{array}{c}\text { Non-breed: } 42 / 70(60,00 \%) \\
\text { Different races: } 28 / 70(40,00 \%)\end{array}$ & $\begin{array}{l}2 \text { months - } 20 \text { years } \\
\left(92 \pm 64,63^{\mathrm{d}}\right)\end{array}$ & $\begin{array}{l}2.0 \text { to } 35.0 \mathrm{~kg} \\
\left(12.0 \pm 9.00^{\mathrm{d}}\right)\end{array}$ \\
\hline
\end{tabular}

${ }^{\mathrm{a}} \mathrm{CG}=$ Control group, ${ }^{\mathrm{b}} \mathrm{MDG}=$ moderate diseases group, ${ }^{\mathrm{c}} \mathrm{SDG}=$ severe diseases group, ${ }^{\mathrm{d}}$ mean \pm standard deviation.

Table 2. Descriptive analysis of the control group of 40 healthy dogs in relation to the C-reactive protein, albumin and C-reactive protein/albumin ratio

\begin{tabular}{|c|c|c|c|}
\hline Variable data & $\mathrm{CRP}^{\mathrm{a}}(\mu \mathrm{g} / \mathrm{mL})$ & Albumin $(\mathrm{g} / \mathrm{dL})$ & $\mathrm{CAR}^{\mathrm{b}}$ \\
\hline Minimum & 0.10 & 2.40 & 0.02 \\
\hline 1st quartile & 0.70 & 2.90 & 0.19 \\
\hline Mean & 1.64 & 3.30 & 0.48 \\
\hline Median & 1.40 & 3.34 & 0.41 \\
\hline 3rd quartile & 2.30 & 3.60 & 0.71 \\
\hline Maximum & 5.20 & 5.10 & 1.57 \\
\hline Standard deviation & 1.26 & 1.27 & 0.08 \\
\hline Coefficient of variation & 0.73 & 0.33 & 0.97 \\
\hline
\end{tabular}

${ }^{\mathrm{a}} \mathrm{CRP}=\mathrm{C}$-reactive protein, ${ }^{\mathrm{b}} \mathrm{CAR}=\mathrm{C}$-reactive protein/albumin ratio. 
for CAR (using the GC of 40 dogs) was 0.36 to 0.60 , with a mean of $0.48(\alpha=5 \%)$ (Fig. $1 \mathrm{~A})$.

Descriptive analyses of the CRP, albumin and CAR variables for sick animals (MDG and SDG) are shown in Tables 3 and 4, respectively. Likewise, the analysis of CAR values in these groups is shown in Figure $1 \mathrm{~B}$ and $1 \mathrm{C}$.

The comparative analysis of the means (and standard deviation) of the variables between groups are listed in Table 5 and allowed to evaluate their correlations with the severity of the underlying diseases. The correlations between the variables studied with LoS and mortality, for sick animals (MDG and SDG), are described in Table 6.
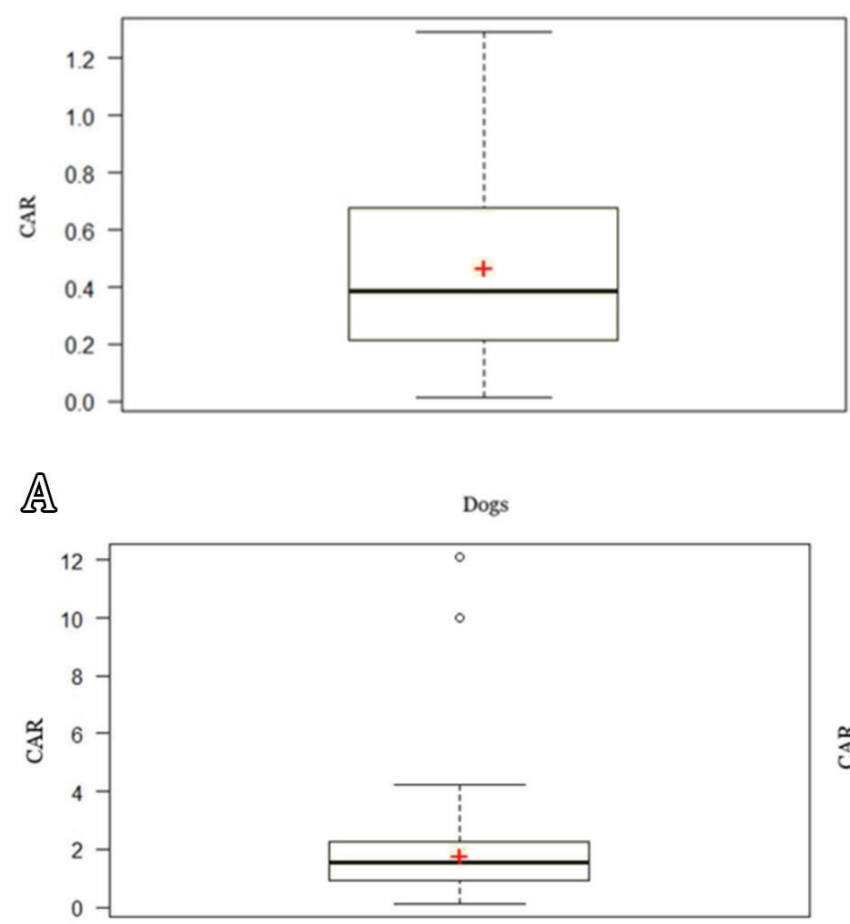

吕

Dogs

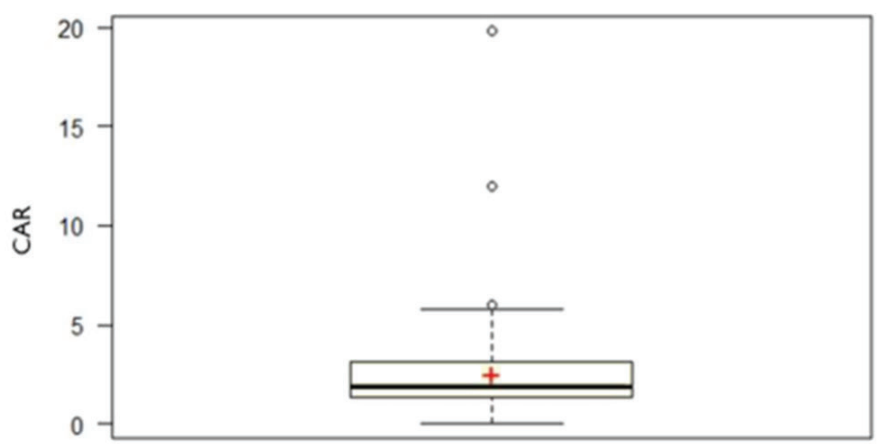

\section{DISCUSSION}

\section{Severity of underlying disease}

In this research, the dogs had a progressive increase in the CAR values as the severity of the underlying disease increased (Table 5), with the mean values in MDG (1.81) and SDG (2.62) being much higher than the reference interval suggested in this study (0.36-0.60). In fact, compared to the upper reference limit, the MDG mean was increased more than three times, and in SDG, this increase was greater than 4.3 times. As expected, the difference in means between groups was statistically significant, proving that CAR is a good marker of disease severity. There are several studies in human
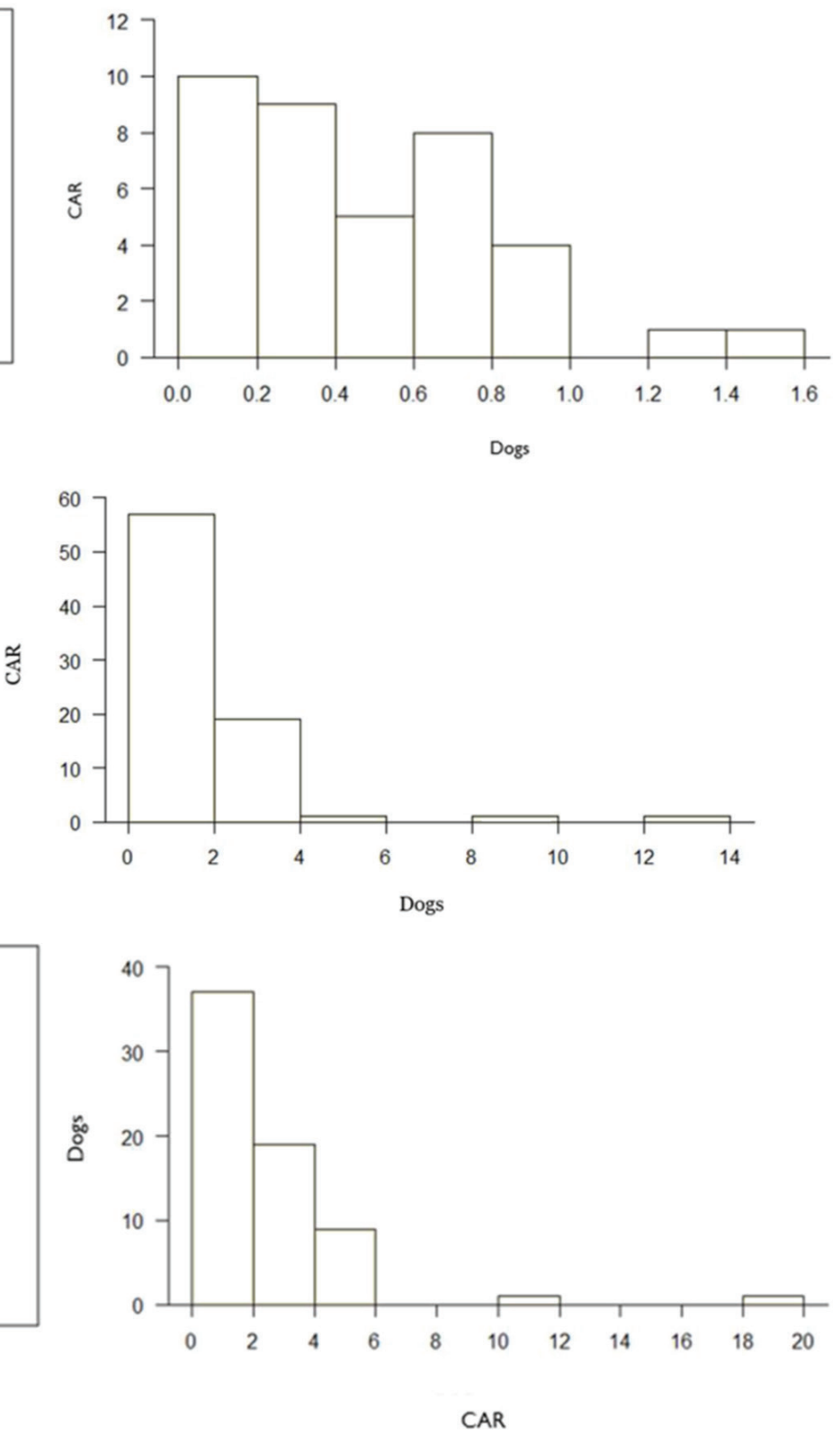

$\mathbb{C}$

Dogs

Fig.1. (A) Box chart and histogram of the C-reactive protein/albumin ratio (CAR) in the Control Group of 40 healthy dogs. (B) Box chart and histogram of the $\mathrm{C}$-reactive protein/albumin ratio (CAR) in the group of 80 dogs with moderate diseases. (C) Box chart and histogram of the C-reactive protein/albumin ratio (CAR) in the group of 70 dogs with severe diseases. The central line of the box plot indicates the median value, the upper, and lower line of the box plot illustrate the range of the $25 \%$ and $75 \%$ of the values, the outer lines at the end of the vertical lines indicate the $95 \%$ and $5 \%$ range of the recorded values. The "+" sign represents the mean. 
Table 3. Descriptive analysis of the group of 80 dogs with moderate systemic diseases in relation to the C-reactive protein, albumin and $\mathrm{C}$-reactive protein/albumin ratio

\begin{tabular}{lccc}
\hline \multicolumn{1}{c}{ Variable data } & $\mathrm{CRP}^{\mathrm{a}}(\mu \mathrm{g} / \mathrm{mL})$ & Albumin $(\mathrm{g} / \mathrm{dL})$ & 0.12 \\
\hline Minimum & 0.40 & 0.30 & 0.93 \\
1st quartile & 3.00 & 1.90 & 1.81 \\
Mean & 3.61 & 2.54 & 1.54 \\
Median & 3.60 & 2.60 & 2.33 \\
3rd quartile & 4.10 & 3.20 & 12.0 \\
Maximum & 13.30 & 5.10 & 1.72 \\
Standard deviation & 1.73 & 0.90 & 0.95 \\
Coefficient of variation & 0.48 & 0.35 &
\end{tabular}

$\overline{{ }^{\mathrm{a}} \mathrm{CRP}}=\mathrm{C}$-reactive protein, ${ }^{\mathrm{b}} \mathrm{CAR}=\mathrm{C}$-reactive protein $/$ albumin ratio.

Table 4. Descriptive analysis of the group of 70 dogs with severe systemic diseases in relation to the C-reactive protein, albumin and C-reactive protein/albumin ratio

\begin{tabular}{lccc}
\hline \multicolumn{1}{c}{ Variable data } & $\mathrm{CRP}^{\mathrm{a}}(\mu \mathrm{g} / \mathrm{mL})$ & Albumin $\mathrm{g} / \mathrm{dL})$ & 0.03 \\
\hline Minimum & 0.10 & 0.57 & 1.31 \\
1st quartile & 3.10 & 1.58 & 2.62 \\
Mean & 4.97 & 2.29 & 1.88 \\
Median & 3.90 & 2.20 & 3.14 \\
3rd quartile & 4.80 & 3.00 & 19.80 \\
Maximum & 59.40 & 6.30 & 2.80 \\
Standard deviation & 7.01 & 1.03 & 1.07 \\
Coefficient of variation & 1.41 & 0.45 &
\end{tabular}

${ }^{\mathrm{a}} \mathrm{CRP}=\mathrm{C}$-reactive protein, ${ }^{\mathrm{b}} \mathrm{CAR}=\mathrm{C}$-reactive protein/albumin ratio.

Table 5. Comparative analysis of death rates and means (with standard deviation) of the variables: length of hospital stay, albumin, C-reactive protein and C-reactive protein/albumin ratio between the Control Group and the diseased dog groups

\begin{tabular}{lccr} 
& & & \multicolumn{2}{c}{ Frequency or means \pm Standard deviation (s) } \\
\cline { 2 - 4 } & Control Group $(\mathrm{n}=40)$ & Moderate diseases group $(\mathrm{n}=80)$ & Severe diseases group $(\mathrm{n}=70)$ \\
\hline Death & $0(0 \%) \mathrm{a}$ & $6(7.5 \%) \mathrm{b}$ & $34(48.57 \%) \mathrm{c}$ \\
LoS $($ days $)$ & $0.34 \pm 1.04 \mathrm{a}$ & $3.18 \pm 2.91 \mathrm{~b}$ & $6.50 \pm 6.92 \mathrm{c}$ \\
CRP $(\mu \mathrm{g} / \mathrm{dL})$ & $1.64 \pm 1.26 \mathrm{a}$ & $3.61 \pm 1.73 \mathrm{~b}$ & $4.97 \pm 7.01 \mathrm{c}$ \\
Albumin $(\mathrm{g} / \mathrm{dL})$ & $3.81 \pm 1.27 \mathrm{a}$ & $2.54 \pm 0.90 \mathrm{~b}$ & $2.20 \pm 1.03 \mathrm{~b}$ \\
CAR & $0.48 \pm 0.08 \mathrm{a}$ & $1.81 \pm 1.72 \mathrm{~b}$ & $2.62 \pm 2.80 \mathrm{c}$
\end{tabular}

$\mathrm{LOS}=$ Length of hospital stay, CRP = C-reactive protein, CAR = C-reactive protein/albumin ratio; a,b,c = equal letters indicate that the variables compared do not differ statistically, while distinct letters indicate a significant difference by the Kruskal-Wallis test at $5 \%$. Reference values: albumin $=2.6$ to $3.3 \mathrm{~g} /$ dL (Thrall et al. 2015), CRP $=<5,0-8,70 \mu \mathrm{g} / \mathrm{mL}$ (Kuribayashi et al. 2003, Kaya et al. 2012, Anziliero et al. 2013).

Tabela 6. Analysis of correlations between C-reactive protein, albumin, and C-reactive protein/albumin ratio with length of hospital stay and death rate in sick dog groups

\begin{tabular}{|c|c|c|c|c|}
\hline \multirow{2}{*}{ Correlation } & \multicolumn{2}{|c|}{ Moderate diseases group } & \multicolumn{2}{|c|}{ Severe diseases group } \\
\hline & $\mathrm{p}$-value & $r$ & p-value & $r$ \\
\hline $\mathrm{CRP}^{\mathrm{a}} \times \operatorname{LoS}^{\mathrm{b}}$ & 0.08 & 0.19 & 0.73 & -0.04 \\
\hline CRP x Death & 0.89 & 0.01 & 0.21 & 0.15 \\
\hline Albumin x LoS & 0.12 & -0.17 & 0.26 & -0.13 \\
\hline Albumin x Death & 0.42 & -0.09 & 0.04 & -0.24 \\
\hline $\mathrm{CAR}^{\mathrm{c}} \times \mathrm{LoS}$ & $<0.01$ & 0.45 & 0.86 & 0.02 \\
\hline CAR x Death & 0.73 & 0.03 & 0.71 & -0.01 \\
\hline
\end{tabular}

$r=$ Pearson correlation coefficient; ${ }^{\mathrm{a}} \mathrm{CRP}=\mathrm{C}$-reactive protein, ${ }^{\mathrm{b}} \mathrm{LoS}=$ length of hospital stay, ${ }^{\mathrm{c}} \mathrm{CAR}=\mathrm{C}$-reactive protein/albumin ratio. 
medicine that corroborate this assertion, demonstrating a proportional elevation of CAR in severe diseases (Wei et al. 2015, He et al. 2016, Toiyama et al. 2016, Wong et al. 2016, Zhang et al. 2017).

Although the CRP values increased proportionally associated with the severity of the underlying disease, in all groups the means were within the normal range (Table 5). That is, in this study, CRP was not a sensitive indicator of disease severity. There are some studies with similar results in human and veterinary medicine (Tvarijonaviciute et al. 2011, Squassoni et al 2011, Kaya et al. 2012, Qin et al. 2016).

It is known that CRP rises more intensely in cases of inflammation, neoplasms and autoimmune diseases. (Anziliero et al. 2013, Venco et al. 2014, Liu et al. 2015). In dogs, the half-life of only six hours causes the serum concentration to normalize rapidly, between one to two days after the lesion ends (Michelsen et al. 2012, Rubio \& Schmidt 2014, Reimann et al. 2016). So as it is an acute phase protein with a short half-life, studied in this research in groups with heterogeneous disease, also containing chronic disorders or noninflammatory diseases, it is understandable their normal means.

In relation to albumin, the groups of sick animals presented subnormal values, with significant differences in relation to the CG, whose mean was within the reference values (Table 5). There was no significant difference between the MDG and SDG values. That is, hypoalbuminemia was indicative of systemic disease, but not of disease intensity. Despite this, works in human medicine report the association between low levels of albumin and disease severity. Thus, CAR was better as an indicator of disease severity than CRP and albumin analyzed separately. Researches in humans showed the same (Ranzani et al. 2013, Kim et al. 2015, Park et al. 2016, Wu et al. 2016).

\section{Length of hospital stay}

A positive correlation was also observed between CAR and LoS in MDG (Table 6), that is, animals with systemic diseases and values of CAR above the reference tended to recover more slowly (in this work, $>3$ days). The CAR was, therefore, the marker of the LoS in this group. In human medicine, this correlation has also been described. (Ranzani et al. 2013, Kim et al. 2015, Zhang et al. 2016, Li et al. 2017). It is interesting to note that neither CRP nor albumin was correlated with LoS in any of the groups studied, i.e., the CAR evaluation is superior as a predictor of LoS than these variables considered in isolation. This conclusion has been previously described (Ranzani et al. 2013, Zhang et al. 2016, Li et al. 2017).

However, the correlation between CAR and LoS was not noticed in SDG ( $p=0.86$, Table 6$)$. This finding may be a consequence of high mortality in this group (approximately 50\%). As the deaths occurred, mostly shortly after hospitalization, the mean LoS was reduced, impairing the correlation analysis between the aforementioned relationship and the time for clinical recovery in dogs with high lethality diseases. Despite this, the average LoS in the SDG (6.5 days) was significantly higher than that in the other groups, which shows that animals that did not die early (and had high CAR values) tended to have a prolonged hospitalization and delayed discharge, which reinforces the validity of this relationship as a prognostic marker. Several human studies support the efficacy and sensitivity of CAR as a prognostic marker (Wei et al. 2015, Xu et al. 2015, He et al. 2016, Guo et al. 2017, Yu et al. 2017).

\section{Mortality}

There was no correlation between the CAR and the death rate in this study (Table 6). However, articles in human medicine, especially in the area of oncology and in patients with sepsis show the opposite. A survey, aiming to analyze the residual effects of inflammation on survival after discharge from an intensive care unit, analyzed the mortality rate six months after a severe sepsis or septic shock event (Kim et al. 2015). Another group of researchers elaborated a similar study, analyzing mortality 90 days after discharge from the ICU with the same profile of patients (Ranzani et al. 2013, Kim et al. 2015). Both groups concluded that CAR was an excellent marker of mortality during follow-up periods (Ranzani et al. 2013, Kim et al. 2015). Numerous studies in oncology emphasize that CAR predicts the mortality of long-term human patients after cancer treatment (Kinoshita et al. 2015, Zhou et al. 2015, Tao et al. 2016, Toiyama et al. 2016, Zhang et al. 2017). Therefore, it is possible to infer that CAR is a better indicator of long-term mortality compared to observations only at the time of hospitalization.

Regarding CRP, there was also no significant correlation with the mortality rate. There are researches in dogs with immune-mediated hemolytic anemia and ehrlichiosis stating the same (Mylonakis et al. 2011, Griebsch et al. 2019). In humans, most published works demonstrate the inverse (Kunitoshi et al. 1999, Yeun et al. 2000, Kristine et al. 2009, Boulware et al. 2011).

However, there was a negative correlation between death and albumin levels in SDG (Table 6); therefore, in dogs with critical diseases, hypoalbuminemia indicates a higher chance of death. In the literature, reports of correlations between low concentrations of albumin and high mortality are extensive (Nakajima et al. 2014, Wang et al. 2014, Garwe et al. 2016, Slee 2016).

\section{CONCLUSIONS}

The reference range of CAR for normality in dogs in this study was 0.36 to 0.60 . This relationship is a better marker of disease severity and LoS than the CRP or albumin analyzed separately.

However, CAR is not a sensitive marker of mortality during the hospitalization period, and serum albumin is better for dogs with critical diseases, for this purpose. Surveys are needed to assess the accuracy of CAR as a predictor of mortality in dogs over the long term (including postadmission).

Acknowledgments.- To Danielle Venturini, Mara Regina Stipp Balarin and the entire team involved in the project.

Conflict of interest statement.-The authors declare no conflicts of interests.

\section{REFERENCES}

Anziliero D., Bazzi E., Pain K.M., Valle S.F. \& Kreutz L. 2013. Determination of serum levels of C-reactive protein (CRP) in dogs with changes in haematological parameters. Ciênc. Anim. Bras. 14(2):265-272. <http:// dx.doi.org/10.5216/cab.v14i2.9054>

Boulware D.R., Hullsiek K.H., Puronen C.E., Rupert A., Baker J.V., French M.A., Bohjanen P.R., Novak R.M., Neaton J.D., Sereti I. \& INSIGHT Study Group 2011. Higher levels of CRP, D-dimer, IL-6, and hyaluronic acid before initiation of antiretroviral therapy (art) are associated with increased risk of AIDS 
or death. J. Infect. Dis. 203(11):1637-1646. <http://dx.doi.org/10.1093/ infdis/jir134><PMid:21592994>

Cerón J.J., Eckersall P.D. \& Martínez-Subiela S. 2008. Acute phase proteins in dogs and cats: current knowledge and future perspectives. Vet. Clin. Pathol. 34(2):85-99. <http://dx.doi.org/10.1111/j.1939-165x.2005.tb00019.x> $<$ PMid:15902658>

Christensen M.B., Langhorn R., Goddard A., Andreasen E.B., Moldal E., Tvarijonaviciute A., Kirpensteijn J., Jakobsen S., Persson F. \& KjelgaardHansen M. 2014. Comparison of serum amyloid A and C-reactive protein as diagnostic markers of systemic inflammation in dogs. Can. Vet. J. 55(2):161-168. <PMid:24489396>

Cockcroft P.D. 2007. Clinical reasoning and decision analysis. Vet. Clin. N. Am., Small Anim. Pract. 37(3):499-520. <http://dx.doi.org/10.1016/j. cvsm.2007.01.011><PMid:17466753>

Corkins M.R., Guenter P., DiMaria-Ghalili R.A., Jensen G.L., Malone A., Miller S., Patel V., Plogsted S., Resnick H.E. \& American Society for Parenteral and Enteral Nutrition 2014. Malnutrition diagnoses in hospitalized patients: United States, 2010. J. Parenter. Enteral Nutr. 38(2):186-195. <http:// dx.doi.org/10.1177/0148607113512154><PMid:24247093>

Dabrowski R., Kostro K. \& Szczubial M. 2013. Concentrations of C-reactive protein, serum amyloid $\mathrm{A}$, and haptoglobin in uterine arterial and peripheral blood in bitches with pyometra. Theriogenology 80(5):494-497.<http:// dx.doi.org/10.1016/j.theriogenology.2013.05.012><PMid:23810209>

Davis C.J., Sowa D., Keim K.S., Kinnare K. \& Peterson S. 2012. The use of prealbumin and C-reactive protein for monitoring nutrition support in adult patients receiving enteral nutrition in an urban medical center. J. Parenter. Enteral Nutr. 36(2):197-204.<http://dx.doi.org/10.1177/0148607111413896> $<$ PMid:21799187>

Eckersall P.D. \& Schmidt E.M. 2014. The final hurdles for acute phase protein analysis in small animal practice. J. Small Anim. Pract. 55(1):1-3. <http:// dx.doi.org/10.1111/jsap.12168><PMid:24387103>

Eckersall P.D. 2008. Proteins, proteomics, and the dysproteinemia, p.117156. In: Kaneko J.J., Harvey J.W., Bruss M.L. (Eds), Clinical Biochemistry of Domestic Animals. 6th. ed. Elsevier, Burlington.

Fabretti A.K., Fonseca I.B., Pancieri I.V.C., Knupp F.C., Bordini D.M. \& Pereira P.M. 2014. Evaluation of clinical, laboratory and electrophoretic profile to determine of the prognosis of hospitalized dogs. Semina, Ciênc. Agrárias 35(6):3113-3126. <http://dx.doi.org/10.5433/1679-0359.2014v35n6p3113>

Friedrichs K.R., Harr K.E., Freeman K.P., Szladovits B., Walton R.M., Barnhart K.F., Blanco-Chavez J. \& American Society for Veterinary Clinical Pathology 2012. ASVCP reference interval guidelines: determination of de novo reference intervals in veterinary species and other related topics. Vet. Clin. Pathol. 41(4):441-453. <3><PMid: 23240820>

Garwe T., Albrecht R.M., Stoner J.A., Mitchell S. \& Motghare P. 2016. Hypoalbuminemia at admission is associated with increased incidence of in-hospital complications in geriatric trauma patients. Am. J. Surg. 212(1):109-115. <http://dx.doi.org/10.1016/j.amjsurg.2015.06.013> $<$ PMid:26414690>

Griebsch C., Arndt G., Raila J., Schweigert F.J. \& Kohn B. 2009. C-reactive protein concentration in dogs with primary immune-mediated hemolytic anemia. Vet. Clin. Pathol. 38(4):421-425. <http://dx.doi.org/10.1111/j.1939165X.2009.00146.X><PMid:19392754>

Guo S., He X., Chen Q., Yang G., Yao K., Dong P., Ye Y., Chen D., Zhang Z., Qin Z., Liu Z., Xue Y., Zhang M., Liu R., Zhou F. \& Han H. 2017. The C-reactive protein/albumin ratio, a validated prognostic score, predicts outcome of surgical renal cell carcinoma patients. BMC Cancer 17(1):171. <http:// dx.doi.org/10.1186/s12885-017-3119-6><PMid: 28264659>

He S., Wang Y., Chen H., Yang L., Liang S., Lu L. \& Chen Y. 2016. C-reactive protein/albumin ratio (CAR) as a prognostic factor in patients with nonmetastatic nasopharyngeal carcinoma. J. Cancer 7(15):2360-2366.<http:// dx.doi.org/10.7150/jca.16443> <PMid: 27994675>
Jitpean S., Holst B.S., Höglund O.V., Pettersson A., Olsson U., Strage E., Södersten F. \& Hagman R. 2014. Serum insulin-like growth factor-I, iron, C-reactive protein, and serum amyloid A for prediction of outcome in dogs with pyometra. Theriogenology 82(1):43-48. <http://dx.doi.org/10.1016/j. theriogenology.2014.02.014><PMid:24661434>

Karlsson I., Wernersson S., Ambrosen A., Kindahl H., Södersten F., Wang L. \& Hagman R. 2013. Increased concentrations of C-reactive protein but not highmobility group box 1 in dogs with naturally occurring sepsis. Vet. Immunol. Immunopathol. 156(1):64-72. <http://dx.doi.org/10.1016/j. vetimm.2013.09.011> <PMid: 24120445>

Kaya B., Sana B., Eris C., Karabulut K., Bat O. \& Kutanis R. 2012. The diagnostic value of D-dimer, procalcitonin and CRP in acute appendicitis. Int. J. Med. Sci. 9(10):909-915.<http://dx.doi.org/10.7150/ijms.4733><PMid: 23236260>

Kim M.H., Ahn J.Y., Song J.E., Choi H., Ann H.W., Kim J.K., Kim J.H., Jeon Y.D., Kim S.B., Jeong S.J., Ku N.S., Han S.H., Song Y.G., Choi J.Y., Kim Y.S. \& Kim J.M. 2015. The C-reactive protein/albumin ratio as an independent predictor of mortality in patients with severe sepsis or septic shock treated with early goal-directed therapy. PloS One 10(7):e0132109. <http://dx.doi. org/10.1371/journal.pone.0132109><PMid:26158725>

Kinoshita A., Onoda H., Imai N.M., Iwaku A., Oishi M., Tanaka K., Fushiya N., Koike K., Nishino H. \& Matsushima M. 2015. The C-reactive protein/albumin ratio, a novel inflammation-based prognostic score, predicts outcomes in patients with hepatocellular carcinoma. Ann. Surg. Oncol. 22(3):803-810. <http://dx.doi.org/10.1245/s10434-014-4048-0> <PMid: 25190127>

Kjelgaard-Hansen M., Strom H., Mikkelsen L.F., Eriksen T., Jensen A.L. \& Luntang-Jensen M. 2013. Canine serum C-reactive protein as a quantitative marker of the inflammatory stimulus of aseptic elective soft tissue surgery. Vet. Clin. Pathol. 42(3):342-345. <http://dx.doi.org/10.1111/vcp.12063> <PMid:23899087>

Kristine H.A., Stig E.B. \& Børge G.N. 2009. Baseline C-reactive protein is associated with incident cancer and survival in patients with cancer. J. Clin. Oncol. 27(13):2217-2224. <http://dx.doi.org/10.1200/JC0.2008.19.8440> <PMid:19289618>

Kunitoshi I., Masahiko T., Shinichiro Y. \& Fukiyama K. 1999. Serum C-reactive protein (CRP) and risk of death in chronic dialysis patients. Nephrol. Dial. Transplant. 14(8):1956-1960.<http://dx.doi.org/10.1093/ndt/14.8.1956> <PMid:10462277>

Kuribayashi T., Shimada T., Matsumoto M., Kawato K., Honjyo T., Fukuyama M., Yamamoto Y. \& Yamamoto S. 2003. Determination of serum C-reactive protein (CRP) in healthy beagle dogs of various ages and pregnant beagle dogs. Exp. Anim. 52(5):387-390. <http://dx.doi.org/10.1538/ expanim.52.387><PMid: 14625403>

Li N., Tian G.W., Wang Y, Zhang H., Wang Z. \& Li G. 2017. Prognostic role of the pretreatment C-reactive protein/albumin ratio in solid cancers: a metaanalysis. Scient. Rep. 7:41298. <http://dx.doi.org/10.1038/srep41298>

Liu X., Sun X., Liu J., Kong P., Chen S., Zhan Y. \& Xu D. 2015. Preoperative C-reactive protein/albumin ratio predicts prognosis of patients after curative resection for gastric cancer. Transl. Oncol. 8(4):339-345. <http:// dx.doi.org/10.1016/j.tranon.2015.06.006><PMid: 26310380>

McClure V., Van Schoor M., Thompson P.N., Kjelgaard-Hansen M. \& Goddard A. 2013. Evaluation of the use of serum C-reactive protein concentration to predict outcome in puppies infected with canine parvovirus. J. Am. Vet. Med. Assoc. 243(3):361-366. <http://dx.doi.org/10.2460/javma.243.3.361> <PMid:23865878>

Michelsen J., Heller J., Wills F. \& Noble G.K. 2012. Effect of surgeon experience on postoperative plasma cortisol and C-reactive protein concentrations after ovariohysterectomy in the dog: a randomised trial. Aust. Vet. J. 91(4):474-478. <http://dx.doi.org/10.1111/j.1751-0813.2012.01013.x><PMid:23186096>

Muir W.W. 2007. Considerations for general anesthesia. In: Tranquilli W.J., Thurmon J.C. \& Grim K.A. 26 (Eds), Lumb and Jones's Veterinary Anesthesia and Analgesia. 4th ed. Blackwell Publishing, Iowa, p.17. 
Mylonakis M.E., Céron J.J., Leontides L., Siarkou V.I., Martinez S., Tvarijonaviciute A., Koutinas A.F. \& Harrus S. 2011. Serum acute phase proteins as clinical phase indicators and outcome predictors in naturally occurring canine monocytic ehrlichiosis. J. Vet. Intern. Med. 25(4):811-817. <http://dx.doi. org/10.1111/j.1939-1676.2011.0728.x>

Nakajima M., Ohno K., Goto-Koshino Y., Fujino Y. \& Tsujimoto H. 2014. Plasma transferrin concentration as a nutritional marker in malnourished dogs with nutritional treatment. J. Vet. Med. Sci. 76(4):539-543.<http://dx.doi. org/10.1292/jvms.13-0583> <PMid: 24366156>

Niewinski G., Starczewska M. \& Kanski A. 2014. Prognostic scoring systems for mortality in intensive care units-the APACHE model. Anaesthesiol. Intensive Ther. 46(1):46-49. <http://dx.doi.org/10.5603/AIT.2014.0010> $<$ PMid:24643928>

Ong C., Han W.M., Wong J.J. \& Lee J.H. 2014. Nutrition biomarkers and clinical outcomes in critically ill children: a critical appraisal of the literature. Clin. Nutr. 33(2):191-197. <http://dx.doi.org/10.1016/j.clnu.2013.12.010> $<$ PMid:24423748>

Park H.C., Kim M.Y. \& Kim C.H. 2016. C-reactive protein/albumin ratio as prognostic score in oral squamous cell carcinoma. J. Korean Assoc. Oral Maxillofac. Surg. 42(5):243-250. <http://dx.doi.org/10.5125/ jkaoms.2016.42.5.243><PMid:27847731>

Qin G., Tu J., Liu L., Luo L., Wu J., Tao L., Zhang C., Geng X., Chen X., Ai X., Shen B. \& Pan W. 2016. Serum albumin and C-reactive protein/albumin ratio are useful biomarkers of Crohn's disease activity. Med. Sci. Monit. 16(22):43934400. <http://dx.doi.org/10.12659/msm.897460> <PMid:27848931>

Rabelo R.C., Arnold C.F. \& Alsua S.C. 2009. RICO score - rapid classification of survival in intensive care. Interrelated variables in dogs. Revta Clín. Vet. 14(78):28-38.

Ranzani O.T., Zampieri F.G., Forte D.N., Azevedo L.C. \& Park M. 2013. C-reactive protein/albumin ratio predicts 90 -day mortality of septic patients. PloS One 8(3):e59321. <http://dx.doi.org/10.1371/journal.pone.0059321> $<$ PMid:23555017>

Reimann M.J., Ljungvall I., Hillström A., Møller J.E., Hagman R., Falk T., Höglund K., Häggström J. \& Olsen L.H. 2016. Increased serum C-reactive protein concentrations in dogs with congestive heart failure due to myxomatous mitral valve disease. Vet. J. 209(5):113-118. <http://dx.doi.org/10.1016/j. tvjl.2015.12.006><PMid:26831162>

Rubio C.P. \& Schmidt E.M. 2014. Acute phase proteins in dogs: possible applications in surgery. Arq. Bras. Med. Vet. 21(4):492-502.

Silva L.M.S., Martins L.F., Santos M.C.F.C. \& Oliveira R.M. 2014. Prognostic indexes in the clinical practice of nursing in intensive care. Revta Eletrôn. Enfermagem 16(1):179-190.<http://dx.doi.org/10.5216/ree.v16i1.22830>

Slee A. 2016. The relationship between malnutrition risk and clinical outcomes in a cohort of frail older hospital patients. Clin. Nutr. 15(1):57-62. <http:// dx.doi.org/10.1016/j.clnesp.2016.06.002><PMid:28531785>

Squassoni G.F., Motheo T.F., Feliciano M.A.R. \& Vicente W.R.R. 2011. Serum concentration of C-reactive protein in healthy, pregnant and bitches with pyometra. Revta Cient. Eletrôn. Med. Vet. 9(17):1-8. <http://faef.revista.inf.br/imagens_arquivos/arquivos_destaque/ IyZHQ6sejBwfAZs_2013-6-26-12-9-27.pdf>

Tao C.J., Chen Y.Y., Jiang F., Feng X.L., Jin Q.F., Jin T., Piao Y.F. \& Chen X. Z. 2016. The C-reactive protein/albumin ratio is an independent prognostic factor for overall survival in patients with nasopharyngeal carcinoma receiving intensity-modulated radiotherapy. J. Cancer 7(14):2005-2011. <http:// dx.doi.org/10.7150/jca.16210> <PMid:27877215>

Thrall M.A., Weiser G., Allison R.W. \& Campbell T. 2015. Laboratory evaluation of plasma and blood serum proteins, p.398-411. In: Ibid. (Eds), Hematology and Veterinary Clinical Biochemistry. 2nd ed. Wiley-Blackwell, New Jersey.

Tizard I.R. 2014. How initiates inflammation, p.12-30. In: Ibid. (Eds), Veterinary Immunology: an introduction. 9th ed. Elsevier, Rio de Janeiro.
Toiyama Y., Shimura T., Yasuda H., Fujikawa H., Okita Y., Kobayashi M., Ohi M., Yoshiyama S., Hiro J., Araki T., Inoue Y., Mohri Y. \& Kusunoki M. 2016. Clinical burden of C-reactive protein/albumin ratio before curative surgery for patients with gastric cancer. Anticancer Res. 36(12):6491-6498. <http:// dx.doi.org/10.21873/anticanres.11248> <PMid:27919972>

Tvarijonaviciute A., Martinez S., Gutierrez A., Ceron J.J. \& Tecles F. 2011. Serum acute phase protein concentrations in dogs during experimentally short-term induced overweight. A preliminary study. Res. Vet. Sci. 90(1):3134. <http://dx.doi.org/10.1016/j.rvsc.2010.05.008><PMid:20553703>

Venco L., Bertazzolo W., Giordano G. \& Paltrinieri S. 2014. Evaluation of C-reactive protein as a clinical biomarker in naturally heartworm-infected dogs: a field study. Vet. Parasitol. 206(1/2):48-54.<http://dx.doi.org/10.1016/j. vetpar.2014.08.018> <PMid:25218887>

Viitanen S.J., Laurila H.P., Lilja-Maula L.I., Melamies M.A., Rantala M. \& Rajamäki M.M. 2014. Serum C-reactive protein as a diagnostic biomarker in dogs with bacterial respiratory diseases. J. Vet. Intern. Med. 28(1):84-91. <http:// dx.doi.org/ 10.1111/jvim.12262><PMid:24351049>

Wang Y., Stavem K., Dahl F.A., Humerfelt S. \& Haugen T. 2014. Factors associated with a prolonged length of stay after acute exacerbation of chronic obstructive pulmonary disease (AECOPD). Int. J. Chron. Obstruct. Pulmon. Dis. 9(1):99-105. <PMid:24477272>

Wei X.L., Wang F., Zhang D.S., Qiu M., Ren C., Jin Y., Zhou Y., Wang D., He M., Bai L., Wang F., Luo H., Li Y. \& Xu R. 2015. A novel inflammation-based prognostic score in esophageal squamous cell carcinoma: the C-reactive protein/albumin ratio. BMC Cancer 2(15):350.<http://dx.doi.org/10.1186/ s12885-015-1379-6><PMid:25934640>

Wong T.C., Su H.Y., Chen Y.T., Wu P.Y., Chen H.H., Chen T.H., Hsu Y.H. \& Yang S.H. 2016. Ratio of C-reactive protein to albumin predicts muscle mass in adult patients undergoing hemodialysis. PLoS One 11(10):e0165403. <http://dx.doi.org/10.1371/journal.pone.0165403><PMid:27768746>

Wu M., Guo J., Guo L. \& Zuo G. 2016. The C-reactive protein/albumin ratio predicts overall survival of patients with advanced pancreatic cancer. Tumour Biol. 37(9):12525-12533. <http://dx.doi.org/10.1007/s13277016-5122-y><PMid:27344157>

Xu X.L., Yu H.Q., Hu W., Song Q. \& Mao W.M. 2015. A novel inflammation-based prognostic score, the $\mathrm{C}$-reactive protein/albumin ratio predicts the prognosis of patients with operable esophageal squamous cell carcinoma. PloS One 10(9):e0138657. <http://dx.doi.org/10.1371/journal.pone.0138657> $<$ PMid:26390126>

Yeun J.Y., Levine R.A., Mantadilok V. \& Kaysen G.A. 2000. C-reactive protein predicts all-cause and cardiovascular mortality in hemodialysis patients. Am. J. Kidney Dis. 35(3):469-476. <http://dx.doi.org/10.1016/s02726386(00)70200-9><PMid:10692273>

Yu S.T., Zhou Z., Cai Q., Liang F., Han P., Chen R. \& Huang X. 2017. Prognostic value of the C-reactive protein/albumin ratio in patients with laryngeal squamous cell carcinoma. OncoTargets Therapy 10(1):879-884. <http:// dx.doi.org/10.2147/OTT.S128391><PMid:28243123>

Zhang F., Ying L., Jin J., Chen K., Zhang N., Wu J., Zhang Y. \& Su D. 2017. The C-reactive protein/albumin ratio predicts long-term outcomes of patients with operable non-small cell lung cancer. OncoTargets Therapy 8(5):88358842. <http://dx.doi.org/10.18632/oncotarget.13053><PMid: 27823974>

Zhang Y., Zhou G.Q., Liu X., Chen L., Li W.F., Tang L.L., Liu Q., Sun Y. \& Ma J. 2016. Exploration and validation of C-reactive protein/albumin ratio as a novel inflammation-based prognostic marker in nasopharyngeal carcinoma. J. Cancer 7(11):1406-1412. <http://dx.doi.org/10.7150/ jca.15401><PMid:27471556>

Zhou T., Zhan J., Hong S., Fang W., Qin T., Ma Y., Yang Y., He X., Zhao Y., Huang Y., Zhao H. \& Zhang L. 2015. Ratio of C-reactive protein/albumin is an inflammatory prognostic score for predicting overall survival of patients with small-cell lung cancer. Scient. Rep. 5(1):10481. <http://dx.doi. org/10.1038/srep10481> <PMid:26084991> 